\title{
Identification of DNA variation in callus derived from Zingiber officinale and anticoagulation activities of ginger rhizome and callus
}

\author{
Asmaa R. Abd El-Hameid', Zakia A. Abo El-kheir², M. S. Abdel-Hady ${ }^{1}$ and Wafaa A. Helmy ${ }^{3 *}$
}

\begin{abstract}
Background: The medicinal plants have been used as alternative treatments for many diseases in many countries. Thus, the possibility of the alteration of some naturally relatively cheap sources into highly valuable products for pharmaceutical and biological importance via tissue culture is investigated in this study. Special attention is needed to estimate the molecular genetic variation between the studied plant and the callus.

Results: Ginger (Zingiber officinale Roscoe) rhizome was affected by various concentrations of cytokinin and auxin for the induction of callus. The highest percentage of callus induction and maximal callus fresh weight was achieved when Murashige and Skoog (MS) medium was supplemented with $2 \mathrm{mg} / \mathrm{l}$ 2, 4-D + 1 mg/l BA. The genetic variations accompanied with in vitro conditions of callus induction was evaluated by four primers of inter-simple sequence repeat (ISSR) that amplified 36 bands. The highest readings for clotting times were found by using the sulfated neutral extract of ginger rhizome at a concentration of $400 \mu \mathrm{g} / \mathrm{ml}$, and the extract of sulfated alkaline plant callus had an anticoagulation activity at $(200 \mathrm{\mu g} / \mathrm{ml})$ comparable to that of a standard preparation of heparin sodium.

Conclusion: These results showed that ginger (Zingiber officinale Roscoe) rhizome was affected by various concentrations of cytokinin and auxin for induction of callus especially when MS was supplemented with $2 \mathrm{mg} / \mathrm{l}$ 2, 4$\mathrm{D}+1 \mathrm{mg} / \mathrm{BA}$. Also, the results of ISSR markers confirmed the occurrence of genetic variations during callus induction process. The results indicated that the sulfated alkaline of ginger rhizome and sulfated aqueous extracts of ginger rhizome and callus exhibited anticoagulant activity. So, it was clear that the addition of sulfate group into the investigated extracts enhances the anticoagulation activities.
\end{abstract}

Keywords: Ginger rhizome (Zingiber officinale), Callus induction, Inter-simple sequence repeat (ISSR), Anticoagulation activity

\section{Introduction}

Ginger (Zingiber officinale Roscoe) is an aromatic plant used as spice and herbal medicines. The non-volatile phenylpropanoid-derived compounds particularly gingerols and shogaols have been given ginger pungent flavor; when the ginger is dried or cooked, gingerols dehydrated to shogaols (Rehman et al. 2011). Many of the different biological activities have been reported to ginger including antibacterial and anti-inflammatory

\footnotetext{
* Correspondence: ahmed_gallab2000@yahoo.com; ahwa1917@gmail.com ${ }^{3}$ Chemistry of Microbial and Natural Products Department, Pharmaceutical and Drug Industries Research Division, National Research Centre, Dokki, Cairo, Egypt

Full list of author information is available at the end of the article
}

properties and antimicrobial activities. Toxicity studies on ginger show no toxicity at the acute toxicity test (Qureshi et al. 1989). The clinical effectiveness of ginger against nausea and vomiting induced by chemotherapy and also that occurs during pregnancy was observed without harmful clinical evidence (Westfall 2004).

Zingiber zerumbet was reported to have analgesic and antipyretic activities (Somchit et al. 2005), anti-giardial activity (Sawangjaroen et al. 2005), anti-amoebic activity (Sawangjaroen et al. 2006), high platelet-activating factor receptor-binding inhibitory effects (Jantan et al. 2005), and leukemia inhibitory activity (Huang et al. 2005). 
Auxins play an important role in callus induction. Also, the different types of auxins can give various effects on callus growth, especially 2,4-D, which is more effective for callus growth compared to other auxins (Baskaran et al. 2006). Callus induction and subsequent differentiation and organogenesis were performed under culture medium conditions and the application of growth regulators in different combinations (Tripathi and Tripathi 2003; Hamideh et al. 2012).

Plant cells cultivated in vitro such as callus or cell suspension culture could potentially be competitive systems for effective production of marketable secondary metabolites possessing biological activities (Sák et al. 2014). Moreover, the production of bioactive secondary metabolites can be enhanced by the treatment of the undifferentiated cells with elicitors (Namdeo 2007). Salicylic acid (Naik and Al-Khayri 2016), yeast extract (Seidel et al. 2002), and glycine (Molnár et al. 2011) are examples of important elicitors that has the capability to induce the secondary metabolites from in vitro cultures.

Molecular markers provide valuable data detecting any genetic changes induced by in vitro conditions of tissue culture. Recently, ISSR has been widely used as a useful molecular marker to assess the genetic variations and somaclonal variability. ISSR analysis based on PCR amplification of genomic DNA using a single primer targets the repeat, with 1-3 bases, and it does not require sequence information; thus, ISSR markers are becoming a useful molecular marker facilitating the biological researches.

Anticoagulant agents are substances which prevent coagulation (clotting) of blood. Plants may serve as the best alternative sources for the development of new anticoagulant agents due to their biological activities (Kumar et al. 2011).

Thus, a major objective of the present study was to illustrate the effect of different concentrations of 2, 4-D and BA on callus induction from young leaf of Zingiber officinale Roscoe and to evaluate the biological activities of the aqueous and sulfated extracts of the studied rhizome and callus. ISSR technique was used to study the genetic varieties between the investigated rhizome and callus.

\section{Material and methods}

\section{Callus induction}

\section{Explant source and sterilization}

The experiments were carried out in the Tissue Culture Laboratory, Botany Department, National Research Centre (NRC). Callus cultures were obtained from fresh buds of forming young leaves separated from the rhizome of $Z$. officinale Roscoe which was kept in the dark at $28 \pm 2{ }^{\circ} \mathrm{C}$ for 30 days for sprouting buds. The explants were washed thoroughly with running tap water for 20 min and sterilized in $70 \%$ ethanol for $2 \mathrm{~min}$, then washed four times with distilled sterilized water and sterilized also with $30 \%$ Clorox solution (containing 5.25\% sodium hypochlorite) with 2 drops of Tween 20 for $20 \mathrm{~min}$, then finally washed with distilled sterilized water. The explants were cultured on MS basal medium (Murashige and Skoog 1962).

\section{Culture media}

The modified MS medium containing different concentrations of auxins and cytokinins as plant growth regulators (PGR) were used as plant media for growth ginger explant. The treatments presented in Table 1 was included $(1.9 \mathrm{~g} / \mathrm{l}$ potassium nitrate, $1.7 \mathrm{~g} / \mathrm{l}$ ammonium nitrate, $0.1 \mathrm{~g} / \mathrm{l}$ myo-inositol (inactive), $0.1 \mathrm{~g} / \mathrm{l}$ glycine, $0.1 \mathrm{~g} /$ 1 nicotinic acid (98\%), $0.1 \mathrm{~g} / \mathrm{l}$ thiamine $\mathrm{HCl}, 0.02 \mathrm{~g} / \mathrm{l}$ adenine sulfate) for each treatment. The $\mathrm{pH}$ value of the medium was adjusted to 5.8 using $1 \mathrm{M} \mathrm{NaOH}$ or $\mathrm{HCl}$, then autoclaved at $121{ }^{\circ} \mathrm{C}$ and a pressure of $1.2 \mathrm{~kg} / \mathrm{cm}^{2}$ for $20 \mathrm{~min}$.

\section{Culture conditions}

The cultures of rhizomes were incubated in a growth chamber at $25^{\circ} \mathrm{C}$ under $16 \mathrm{~h}$ photoperiod (irradiance of about $25 \mu \mathrm{mol} / \mathrm{m}^{2} \mathrm{~s}$ provided by cool white fluorescent lamps) for 1 month. The sub-culturing were carried out after 4 weeks from incubated culture. The explants were inoculated into media with four replicates. The callus induction percentage was calculated using the following formula:

$$
\text { Callus induction }(\%)=\frac{\text { Number of explants induced callus }}{\text { Total number of explants inoculated }} \times 100
$$

\section{Genetic analysis of ginger plant and callus using ISSR marker}

Extraction and purification of genomic DNA was done according to Niu et al. (2008). Plant leaf tissue of ginger $(0.1 \mathrm{~g})$ and of their calli $(0.5 \mathrm{~g})$ were ground separately to a fine powder using liquid nitrogen. Each sample received $800 \mu \mathrm{l}$ of cetyltriethyl ammonium bromide (CTAB) extraction buffer $(100 \mathrm{mM}$ Tris- $\mathrm{HCl}(\mathrm{pH} 8.0)$, 1.4 M NaCl, $20 \mathrm{mM}$ EDTA (pH 8.0), $2 \% \mathrm{w} / \mathrm{v}$ of CTAB from Sigma Chemical, USA, [just prior to use the solution was adjusted to $0.2 \%(\mathrm{v} / \mathrm{v}) \quad \beta$-mercaptoethanol]) which was added, and the contents were mixed. Each

Table 1 MS media supplemented with different growth regulators at different concentrations for callus induction from ginger explant

MS media composition

1. MS $(4.4 \mathrm{~g} / \mathrm{l})+$ sucrose $(30 \mathrm{~g} / \mathrm{l})+\operatorname{agar}(8 \mathrm{~g} / \mathrm{l})+3 \mathrm{mg} / \mathrm{l}(2,4-\mathrm{D})+1 \mathrm{mg} / \mathrm{l}$
2. MS $(4.4 \mathrm{~g} / \mathrm{l})+$ sucrose $(30 \mathrm{~g} / \mathrm{l})+\operatorname{agar}(8 \mathrm{~g} / \mathrm{l})+2 \mathrm{mg} / \mathrm{l}(2,4-D)+1 \mathrm{mg} / \mathrm{l}$
(BA)
3. MS $(4.4 \mathrm{~g} / \mathrm{l})+$ sucrose $(30 \mathrm{~g} / \mathrm{l})+\operatorname{agar}(8 \mathrm{~g} / \mathrm{l})+0.5 \mathrm{mg} / \mathrm{l}(2,4-D)+0.5$
$\mathrm{mg} / \mathrm{l}(\mathrm{BA})$ 
tube was incubated at $65^{\circ} \mathrm{C}$ for $15 \mathrm{~min}$ to lyse the cell. A volume of $225 \mu \mathrm{l}$ of $2 \mathrm{M}$ potassium acetate were added and gently mixed. Samples were incubated on ice for 15 $\mathrm{min}$. The tubes were centrifuged at $12,000 \mathrm{~g}$ for $10 \mathrm{~min}$ at room temperature. The supernatant were transferred to a clean tube followed by an equal volume of isopropanol. The precipitated DNA was centrifuged at 12,000 $g$ for 10 min at room temperature for forming pellet. The pellet was washed with $0.5 \mathrm{ml}$ of $70 \%$ ethanol then air- or vacuum-dried and dissolved in $50-200 \mu \mathrm{l}$ of TE buffer $(10 \mathrm{mM}$ Tris- $\mathrm{HCl}$ and $1 \mathrm{mM}$ EDTA (pH 8.0)) or $300 \mu \mathrm{l}$ of $\mathrm{ddH}_{2} \mathrm{O}$. The DNA concentration was measured using UV spectrophotometer. The DNA is pure enough at [OD 260/280 = 1.68] (Sambrook and Russell 2000). The quality of the DNA were checked on $1 \%$ of agarose gel in $0.5 \times$ TAE buffer $(10 \mathrm{mM}$ Tris- $\mathrm{HCl}$ and $0.5 \mathrm{mM}$ EDTA (pH 9.0)).

Inter-simple sequence repeat (ISSR) of the amplification reaction (PCR) was carried out in $25 \mu \mathrm{l}$ total reaction mix containing $2 \mu \mathrm{l}(20 \mathrm{ng})$ template DNA, $2.5 \mu \mathrm{l}(2$ $\mathrm{mM})$ dNTPs, $3 \mu \mathrm{l}(10$ pmole) primer of each primers listed in Table 2, $2.5 \mu \mathrm{l}(1.5 \mathrm{mM}) \mathrm{MgCl}_{2}, 5 \mu \mathrm{l} 10 \times$ buffer $0.25 \mu \mathrm{l}(5 \mathrm{U} / \mathrm{ml})$ Taq DNA polymerase (Promega, USA), and $9.75 \mathrm{ddH}_{2} \mathrm{O}$. PCR amplification was carried out using Biometra Cycler (Gottingen, Germany). Forty cycles were performed, after an initial denaturation step for $5 \mathrm{~min}$ at $94^{\circ} \mathrm{C}$. Each cycle consisted of a denaturation step $94{ }^{\circ} \mathrm{C}$ at $30 \mathrm{~s}$, annealing at $45^{\circ} \mathrm{C}$ for $45 \mathrm{~s}$, and extension at $72^{\circ} \mathrm{C}$ for $1 \mathrm{~min}$. The final extension step was performed for $5 \mathrm{~min}$ at $72^{\circ} \mathrm{C}$.

The amplification products were analyzed by electrophoresis in $1 \%$ agarose gel in $0.5 \times$ TBE buffer and detected by ethidium bromide (Sigma-Aldrich). Further, a 1-kb DNA ladder (Sib Enzyme Ltd., Russia) was used as molecular size standard. PCR products were visualized by UV trans-illuminator and photographed with gel documentation system.

Table 2 List of ISSR primers, their sequences, and their annealing temperature

\begin{tabular}{lll}
\hline Primer & Sequence $\left(5^{\prime} \rightarrow 3^{\prime}\right)$ & Annealing temp. $\left[{ }^{\circ} \mathrm{C}\right]$ \\
\hline 807 & AGA GAG AGA GAG AGA GT & 50 \\
810 & GAG AGA GAG AGA GAG AT & 50 \\
823 & TCT CTC TCT CTC TCT CC & 52 \\
826 & ACA CAC ACA CAC ACA CC & 52 \\
844 & CTC TCT CTC TCT CTC TC & 55 \\
848 & CAC ACA CAC ACA CAC AAG & 52 \\
SPS1 & GAC GAC GACGAC GAC & 52 \\
SPS03 & GAC AGA CAG ACA ACA & 48 \\
SPS08 & GGA GGAGGAGGA & 40 \\
SPS9 & CAA CAA CAACAA CAA & 38 \\
\hline
\end{tabular}

Preparation of aqueous extracts for ginger plant and callus Extraction process was carried out by Jindal and Mukherjee (1970) at different $\mathrm{pH}$ conditions for each investigated variety sample either with $\mathrm{HCl}(\mathrm{pH} 3)$, water ( $\mathrm{pH} 7$ ), or $\mathrm{NaOH}$ ( $\mathrm{pH} 10)$. Briefly, defatted powdered plant material of ginger rhizome and callus $(5 \mathrm{gm})$ was extracted with $200 \mathrm{ml}$ of extracting solvents at $85^{\circ} \mathrm{C}$ for $3 \mathrm{~h}$. After filtration, the extracts were neutralized and dialyzed against distilled water for $48 \mathrm{~h}$, dried and weighted.

\section{Preparation of sulfated extracts}

The performance of sulfated extracts was according to Yang et al. (2005) with some modifications. The sulfation of the extract was performed as follows: $0.1 \mathrm{~g}$ of each extract was suspended in $0.5 \mathrm{ml}$ dry formamide and the mixture was stirred at room temperature for $24 \mathrm{~h}$. In order to disperse it into the solvent, a sulfating agent was prepared by dropping $1 \mathrm{ml}$ of chlorosulfonic acid $\left(\mathrm{HClSO}_{3}\right)$ in $4 \mathrm{ml}$ of formamide under cooling in an ice water bath and then added to the extract. The reaction was cooled in ice, neutralized by $30 \% \mathrm{NaOH}$ solution and dialyzed against running water for $48 \mathrm{~h}$, and then lyophilized.

\section{Evaluation of biological activities}

Anticoagulation activities of the various aqueous and sulfated extracts of ginger plant and callus preparations were determined according to the time for clot formation (Colman et al. 1994) and compared with that of the standard heparin sodium preparation.

Hard glass, $31 \times 100-\mathrm{mm}$ test tubes were cleaned by immersion overnight in chromic acid. To each tube was added $0.8 \mathrm{ml}$ of sample solution (0.01\%), $0.8 \mathrm{ml}$ of standard heparin sodium solution (1.4 USP units $/ 0.8 \mathrm{~mL}$ ), or $0.8 \mathrm{ml}$ saline solution. To each tube so prepared, $1 \mathrm{ml}$ of the plasma and $0.2 \mathrm{ml}$ of calcium chloride solution were added. The time was immediately recorded and each tube was closed with a stopper and the contents were mixed by inverting three times in such a way that the entire inner surface of the tube was wet. The time required for clotting was determined.

\section{Statistical analysis}

All in vitro culture experiments were designed in a completely randomized design in triplicate. The percentage of callus induction (\%), callus color, texture of callus, and callus fresh weight means \pm standard deviation (SD) were calculated. The amplified DNA polymorphic fragments were presented for each ISSR primer according presence (1) or absence (0) analyzed by using Total Lab (T.L. 120) program. Fragments were arranged according to their molecular weight size. 


\section{Results}

\section{Callus induction}

Callus induction from young leaves (sprouted buds) of Zingiber officinale rhizome cultured on modified MS with various concentrations of growth regulators in Table 3. Generally on culturing the explants on MS medium supplemented with auxin, the generated calli were emerged at the edges of explant within 15 days of culture. MS medium supplemented with auxin produced swollen callus after 15 days which emerged at the cut edges.

Various auxin concentrations used in the present study produced different types of callus morphology; the callus induction percentages were listed in Table 3 . The percentages of callus induction indicated that the highest callus induction was achieved when MS is supplemented with $2 \mathrm{mg} / \mathrm{l} 2,4-\mathrm{D}$ in combination with $1 \mathrm{mg} / \mathrm{l} \mathrm{BA} \mathrm{(81 \% ),} \mathrm{while} \mathrm{the} \mathrm{lowest}$ $66.6 \%$ callus induction appeared when using equal concentrations of auxin and cytokines $(0.5 \mathrm{mg} / \mathrm{l})$.

The data represented in Table 3 also indicated that the highest callus fresh weight $(3.89 \mathrm{~g} /$ explant) was obtained when explants from the ginger cultured on the medium is supplemented with 2,4-D (2 mg/l) and BA (1 mg/l) compared with the lowest fresh weight $2.93 \mathrm{~g} /$ explant obtained on the medium with 2,4-D (3 mg/l) + BA (1 mg/l).

Our results showed that the percentage of callus induction and the callus weight were influenced by BA concentration. Using MS medium with various concentrations of growth regulators produced the variety of color and texture of callus. The friable callus were formed on MS medium supplemented with $2 \mathrm{mg} / \mathrm{l}$ 2,4-D and $1 \mathrm{~m} / \mathrm{g}$ BA. While the greenish white and compact calli were formed on MS medium with 2,4-D in combination with BA at equal concentrations $(0.5 \mathrm{mg} / \mathrm{l})$. However, relatively greenish yellow and granulated appearance of calli were observed at $3 \mathrm{mg} / \mathrm{l} 2$, 4-D in combination with $1 \mathrm{mg} / \mathrm{l} \mathrm{BA}$.

\section{Molecular studies}

Numerous molecular markers have been developed to assess the genetic variations accompanied to in vitro derived calli. Genomic DNA isolated by using CTAB method from plant and callus induced in tissue culture, and amplified by PCR using ISSR primers, was widely reported. This protocol was also found to be suitable for the extraction of genomic DNA from leaves and also from calli.

In the present study prior to ISSR analysis, primer annealing temperature was standardized for individual primers using gradient PCR, which varied from 38 to $55^{\circ} \mathrm{C}$. Optimization of the annealing was tested to obtain the best PCR performance. Amplification products were separated by agarose gel electrophoresis to reveal band polymorphism. In these PCR reactions, the concentrations of 30-100 ng of DNA template and $5 \mathrm{mM} \mathrm{MgCl}_{2}$ gave the best result. Among the 10 primers (807, 810, 844, 823, 826, 848, SPS1, SPS9, SPS3, SPS8) used for initial screening, four primers $(810,844,823,826)$ generated different bands with ginger rhizome and calli (Table 4).

Thirty-six bands were generated using the four primers in the case of plant and from the callus induced on MS medium supplemented with $2 \mathrm{mg} / \mathrm{l}$ 2,4-D and $1 \mathrm{mg} / \mathrm{l} \mathrm{BA}$. The size of the DNA fragments ranged from 100 to 1000 bp (Fig. 1). The amplified product varied between 309 and 971 bp (Table 4). Genetic changes induced by in vitro conditions of tissue culture are expected to generate stable plants carrying interesting heritable trait. Gel electrophoresis pattern obtained using ISSR primers were illustrated in Fig. 1. The identical ISSR banding patterns of plant and callus and also the resultant multiple band patterns were summarized Table 4.

In this study, the amplified DNA polymorphic fragments were scored as presence (1) or absence (0) (Table 4). ISSR primers used in the present study showed some polymorphic bands during in vitro culture (Fig. 1) with primer (810) which showed differences in bands at $919 \mathrm{bp}$ with plant and absent in callus culture, while two bands at 824 and $309 \mathrm{bp}$ appeared only with callus culture. In this primer, detected were three polymorphic bands with $42.86 \%$ polymorphism. ISSR marker generated with primer (823) showed differences in the band at $429 \mathrm{bp}$ with plant, but another band at $563 \mathrm{bp}$ with callus. There were two polymorphic bands with $25 \%$ polymorphism.

The primer (826) showed the presence of one band at $824 \mathrm{bp}$ in the callus culture only as a polymorphic band with $11.11 \%$ polymorphism. There was no difference in

Table 3 Effect of different concentration 2,4-D and BA on the response of callus induction (\%) from young leaves of Z. officinale Roscoe and means of callus fresh weight after 4 weeks

\begin{tabular}{|c|c|c|c|c|c|}
\hline \multicolumn{2}{|c|}{ *Growth regulators' concentration (mg/l) } & \multirow{2}{*}{$\begin{array}{l}\text { Callus induction } \\
(\%)\end{array}$} & \multirow{2}{*}{$\begin{array}{l}\text { Mean fresh weight } \\
\text { of callus (g/explant) }\end{array}$} & \multirow[t]{2}{*}{ Color of callus } & \multirow[t]{2}{*}{ Texture } \\
\hline $2,4-D$ & $\mathrm{BA}$ & & & & \\
\hline 0.0 & 0.0 & 0.0 & $0.0 \pm 0.0$ & - & - \\
\hline 3.0 & 1.0 & $75 \pm 0.15$ & $2.93 \pm 0.09$ & Greenish yellow & Granulated \\
\hline 2.0 & 1.0 & $81 \pm 0.40$ & $3.89 \pm 0.22$ & White & Friable \\
\hline 0.5 & 0.5 & $66.6 \pm 0.32$ & $2.98 \pm 0.20$ & Greenish white & Compact \\
\hline
\end{tabular}

Values expressed as mean \pm SD

*2,4-D dichlorophenoxyacetic acid, $B A$ benzyl adenine 
Table 4 Polymorphic fragments of ISSR primers and the sizes of polymorphic PCR products between ginger and callus

\begin{tabular}{|c|c|c|c|c|c|c|c|c|c|}
\hline \multirow{2}{*}{$\begin{array}{l}\text { Band } \\
\text { no. }\end{array}$} & \multirow{2}{*}{$\begin{array}{l}\text { Band } \\
\text { sizes } \\
\text { (bp) }\end{array}$} & \multicolumn{2}{|c|}{ Primer 810} & \multicolumn{2}{|c|}{ Primer 823} & \multicolumn{2}{|c|}{ Primer 826} & \multicolumn{2}{|c|}{ Primer 844} \\
\hline & & $\bar{G}$ & $C$ & $\bar{G}$ & $C$ & $\bar{G}$ & $C$ & $\bar{G}$ & $C$ \\
\hline 1 & 971 & - & - & - & - & - & - & + & + \\
\hline 2 & 919 & + & - & - & - & - & - & - & - \\
\hline 3 & 824 & - & + & - & - & - & + & + & + \\
\hline 4 & 781 & - & - & + & + & - & - & - & - \\
\hline 5 & 700 & - & - & + & + & + & + & + & + \\
\hline 6 & 595 & + & + & - & - & - & - & - & - \\
\hline 7 & 563 & - & - & - & + & + & + & - & - \\
\hline 8 & 533 & - & - & - & - & - & - & + & + \\
\hline 9 & 478 & + & + & - & - & - & - & - & - \\
\hline 10 & 453 & - & - & - & - & + & + & + & + \\
\hline 11 & 429 & - & - & + & - & - & - & - & - \\
\hline 12 & 364 & - & - & - & - & + & + & + & + \\
\hline 13 & 345 & - & - & + & + & - & - & - & - \\
\hline 14 & 309 & - & + & - & - & - & - & - & - \\
\hline
\end{tabular}

Presence (+) or absence (-) of bands are indicated

$G$ ginger plant, $C$ callus

the amplified fragments generated with primer (844) between ginger rhizome and its callus and no polymorphic bands appeared in Fig. 1.

The results obtained in the present study showed the presence of some genetic variations at the DNA level during in vitro culture. The genetic variations associated with tissue culture of ginger plant by using inter-simple sequence repeat (ISSR) markers may be occurred as a result of the callus culture on medium supplemented with
2,4-D; thus, ISSR could be useful in detecting the presence of genetic variation in the initial stages of callus development.

PCR-based polymorphisms can be random or specific depending on the type of the primer used. Inter-simple sequence repeat (ISSR) amplification polymorphism is also a powerful technique for detection of somaclonal variation.

\section{Biological activities of ginger rhizome and callus extracts}

A possible anticoagulation properties of the aqueous extracts of ginger rhizome and callus were also assessed in the present study. Thus, further investigation was directed towards the promotion of these biological activities (anticoagulation) throughout chemical modification of the native aqueous extracts. This was achieved by introducing sulfate ester groups on carbohydrate moieties of the tested aqueous extracts.

\section{In vitro testing of extracts for anticoagulation activity}

In this part of study, there was an important assay to evaluate the anticoagulation activity of aqueous extracts (acidic, neutral, and alkaline) and their corresponding sulfated derivatives of both ginger rhizome and its callus. The results showed that some of the aqueous extracts (acidic, neutral, alkaline, and sulfated acidic) of the ginger plant have no anticoagulation activities at $2000 \mu \mathrm{g} / \mathrm{ml}$ concentration. The highest readings for clotting times were found by using the sulfated neutral extract of ginger rhizome at a concentration of $400 \mu \mathrm{g} / \mathrm{ml}$. The lowest readings for clotting time was noticed by using sulfated alkaline extract of callus at a concentration $(1000 \mu \mathrm{g} / \mathrm{ml})$ comparable to that of a standard preparation of heparin sodium. On the other hand, the extract of sulfated alkaline plant callus had anticoagulation activity at

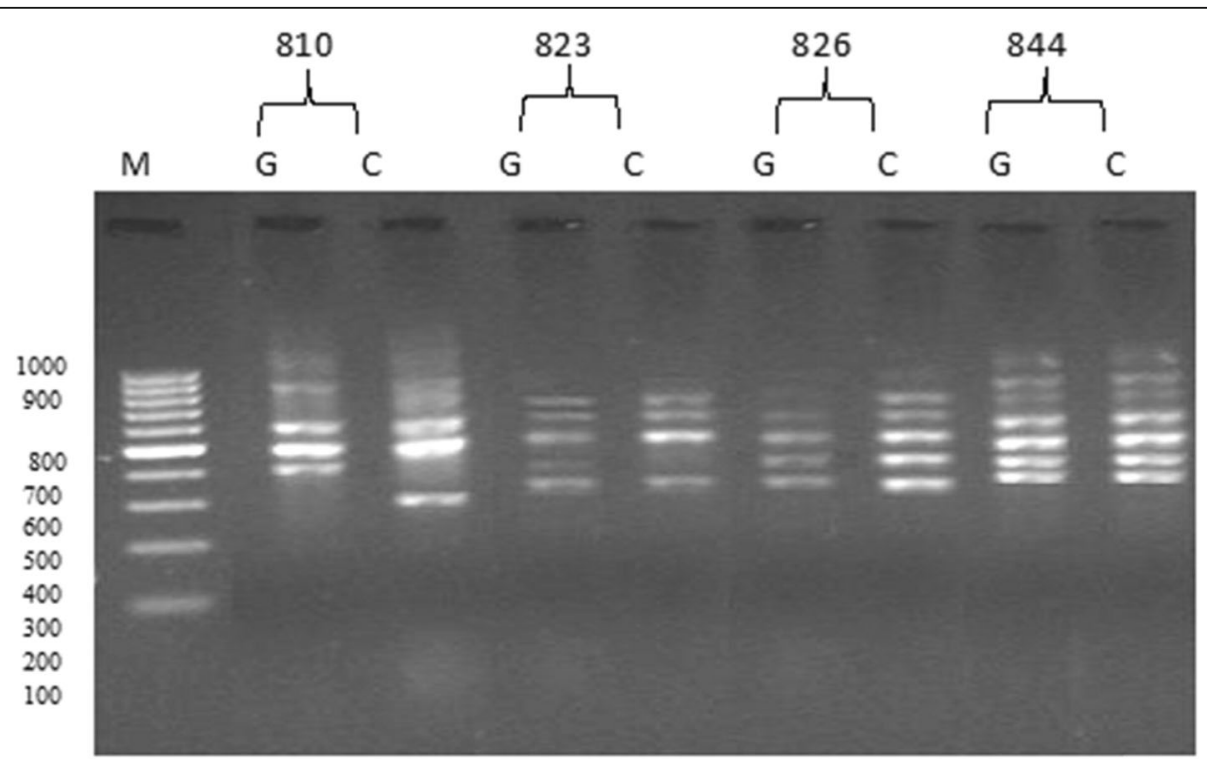

Fig. 1 Banding pattern obtained with ISSR primers of ginger and callus. M marker, G ginger plant, C callus 
$200 \mu \mathrm{g} / \mathrm{ml}$. From the obtained data, it was concluded that the addition of sulfate group into the investigated extracts enhance the anticoagulation activities.

\section{Discussion}

The effect of plant growth regulator on callus induction Callus formation is the important stage in tissue culture processes for the establishment of cell suspension cultures (Kumar and Kanwar 2007; Ngara et al. 2008). The results in Table 3 showed that the combination of auxin with cytokinin can produce callus from leaf explant, but MS medium supplemented with $2 \mathrm{mg} / \mathrm{l} 2,4-\mathrm{D}$ with $1 \mathrm{mg} / \mathrm{l} \mathrm{BA}$ 2,4-D was effective for callus induction. These results in the present study are in lined with other researches because 2,4-D is the primary auxin which is used for the callus induction reported by Hamideh et al. (2012).

The ability of different explants to produce callus and regeneration plants depend on different conditions of cultivation. The formation of calli from leaves, nodal segment, and internode were obtained on MS medium supplemented with NAA $1 \mathrm{mg} / \mathrm{l}$ and BA $1 \mathrm{mg} / \mathrm{l}$, while the best result of calli from shoot tip was obtained on MS with $0.5 \mathrm{mg} / \mathrm{l}$ 2,4-D and $0.5 \mathrm{mg} / 1 \mathrm{kin}$ (Lashin and Mamdouh 2014).

Previous results reported that leaf explant of ginger gave the best result over shoot tip and root explant for callus induction (Sultana et al. 2009). Various auxin concentrations about $1-2 \mathrm{mg} / \mathrm{l} 2,4-\mathrm{D}$ was reported to be an effective plant growth regulator (PGR) that produced rapid proliferating friable callus in Curcuma amada (Prakash et al. 2004). A survey of literature shows that high concentrations of auxins as well as cytokinins used for callus induction, but a maximum of $75 \%$ callusing, was observed only after a month. The maximum frequency of callus was $86 \%$ by the combinations of $1.5 \mathrm{mg} / \mathrm{l} 2,4-\mathrm{D}$ and $0.5 \mathrm{mg} / \mathrm{l}$ of BA (Abirami and Kumar 2013). Dehghani et al. (2011) indicated that the best results for production of $70 \%$ of callus from ginger rhizomes were obtained in the combination of 2,4-D and kin.

In this study, it was found that the variations in color and texture of callus were affected by the type and concentration of PGR in the culture medium. The previous results, $1-2 \mathrm{mg} / \mathrm{l} 2,4-\mathrm{D}$, were reported to be an effective PGR that produced rapid proliferating friable callus in Curcuma amada (Prakash et al. 2004), Gymnema sylvestris (Roy et al. 2008), and Brassica napus (Jonoubi et al. 2005) in vitro cultures. These results could be attributed to the fact that synthetic PGRs are more stable in their ability to withstand physical and enzymatic degradation than naturally occurring auxins (Pierik 1990).

\section{Molecular studies}

Inter-simple sequence repeat (ISSR) are semi-arbitrary markers amplified by polymerase chain reaction (PCR) in the presence of one primer complementary to a target microsatellite; it does not require genome sequence information, which leads to multilocus and produces dominant markers (Zietkiewicz et al. 1994; Mishra et al. 2003).

PCR amplification was difficult for some of the plants which contain high amounts of polysaccharides and polyphenols. A special technique for studying genomic polymorphism of callus culture in succulents and other plants was eliminating DNA contaminants (Diadema et al. 2003).

In the present study, during the formation of callus, the genetic changes occurred which are associated with callus culture conditions. ISSR primers used in the present study showed some polymorphic bands during in vitro culture in Table 4 and Fig. 1 . The results obtained by Joy and Raja (2010) showed that the detection of genetic variation associated with the tissue culture of Jasminium auriculatum by RAPD markers may occur as a result of mutations during callus culture in the presence of 2,4-D in the medium which could be applied in the breeding of this species. Other studies were detected the somaclonal variation in potato callus using RAPDPCR (Bordallo et al. 2004; Ehsanpour et al. 2007).

Plant tissue culture media, $\mathrm{pH}$, and salinity lead to higher polymorphism (Dakah et al. 2015). However, the electrophoretic pattern variation of genomic DNA from Ananas bracteatus callus was induced after 120 days of culture, probably due to the medium supplementation with 2,4-D (Costa and Zaffari 2005). Somaclonal variability often arises in tissue culture as a manifestation of epigenetic influence or changes in the genome of differentiating vegetative cell induced by tissue culture conditions (Larkin and Scowcroft 1981; Muller et al. 1990). In the recent study of Elshafei et al. (2019), the genetic variation were detected among rice cultivars and somaclons regenerated from rice calli by using RAPD technique.

\section{Evaluation of the anticoagulation activity of ginger aqueous extracts}

Anticoagulation properties were evaluated to the aqueous extracts and their corresponding sulfated derivatives of ginger rhizome and callus. We noticed a variety of readings for clotting time comparing with a standard preparation of heparin sodium. This observation is acceptable on the basis of the previously mentioned (Mendes-Silva et al. 2003). The aqueous extract of Zingiber officinale possesses anticoagulant properties through prevention of coagulation process and clot formation (Taj Eldin et al. 2016). According to the report by ShikhaJ et al. (2014), phytochemicals present in plants having anticoagulant properties can ultimately reduce or eliminate the risk of thromboembolic diseases. 


\section{Conclusion}

The possibility of the alteration of some naturally relatively cheap sources into highly valuable products of pharmaceutical and biological importance via tissue culture was investigated in this study. Special attention is needed to estimate the molecular genetic variation between the studied plant and callus. These results showed that the ginger (Zingiber officinale Roscoe) rhizome was affected by various concentrations of cytokinin and auxin for the induction of callus. The highest induction of callus and maximal callus fresh weight was achieved

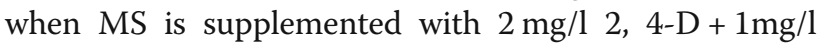
BA. The highest readings for clotting times were found by using the sulfated neutral extract of ginger rhizome at a concentration of $400 \mu \mathrm{g} / \mathrm{ml}$, and the extract of sulfated alkaline plant callus had an anticoagulation activity at $200 \mu \mathrm{g} / \mathrm{ml}$ comparable to that of a standard preparation of heparin sodium. From the obtained data, it was concluded that the addition of sulfate group into the investigated extracts enhance the anticoagulation activities.

\section{Abbreviations}

MS: Murashige and Skoog's medium; 2,4-D: 2,4-Dichlorophenoxyacetic acid; BA: 6-Benzylaminopurine; DNA: Deoxyribonucleic acid;

dNTP: Deoxynucleoside triphosphate; EDTA: Ethylenediaminetetraacetic acid; TE: Tris-EDTA; Bp: Base pair; RAPD: Random amplified polymorphic DNA

\section{Acknowledgements}

The authors are highly thankful to the National Research Centre for providing financial assistance to carry out this research.

\section{Authors' contributions}

Dr. Asmaa R. Abd El-Hameid has done and conducted all the practical experiments. All authors share in every step of this work and all of them contribute in writing the manuscript. All authors read and approved the final manuscript.

\section{Funding}

Not applicable

\section{Availability of data and materials}

The datasets generated and/or analyzed during the current study are included in this published manuscript.

\section{Ethics approval and consent to participate}

Not applicable

\section{Consent for publication}

Not applicable

\section{Competing interests}

The authors declare that they have no competing interests.

\section{Author details}

${ }^{1}$ Botany Department, National Research Centre, Dokki, Giza, Egypt. ${ }^{2}$ Department of Botany and Microbiology, Faculty of Science, Al-Azhar University, Cairo, Egypt. ${ }^{3}$ Chemistry of Microbial and Natural Products Department, Pharmaceutical and Drug Industries Research Division, National Research Centre, Dokki, Cairo, Egypt.

Received: 1 December 2019 Accepted: 4 February 2020 Published online: 18 February 2020

\section{References}

Abirami H, Kumar PS (2013) In vitro regeneration and extraction of secondary metabolites in Aegle marmelos (L.) Correa. Asian J Plant Sci Res 3(2):99-106
Baskaran P, Rajeswari BR, Jayabalan N (2006) Development of an in vitro regeneration system in sorghum [Sorghum bicolor $(\mathrm{L})$. Moench] using root transverse thin cell layers (tTCLs). Turk J Bot 30:1-9

Bordallo PN, Silva DH, Maria J, Cruz CD, Elizabeth P, Fontes EP (2004) Somaclonal variation on in vitro callus culture potato cultivars. Hort Bras Bras 22(2):300-304

Colman RW, Hirsh J, Marder VJ (1994) Haemostasis and thrombosis: basic principles and practice, Lippincott Company JB, pp 759-762

Costa F, Zaffari GT (2005) Micropropagação de Ananas bracteatus (Shultz) cv. striatus. Hort Rev Bras HortOrnamenta 11:109-113

Dakah A, Suleiman M, Zaid S (2015) Genetic relationship among wild medicinal genotypes of Ziziphor acanescens Benth. and Ziziphor atenuior L. and detection of genetic variations resulted from tissue culture, salinity and $\mathrm{pH}$ media. Amer J Agricul Biolo Sci 10(3):144-156

Dehghani I, Mostajerana A, Asgharib G (2011) In vitro and in vivo production of gingerols and zingiberene in ginger plant (Zingiber officinale Roscoe). Iran J of Pharm Sci 7(2):117-121

Diadema K, Baumel A, Lebris M, Affre L (2003) Genomic DNA isolation and amplification from callus culture in succulent plants, Carpobrotus species (Aizoaceae). Plant MolBiol Rep 21:173a-173e

Ehsanpour AA, Madani S, Hoseini M (2007) Detection of somaclonal variation in potato callus induced by UV-C radiation using RAPD-PCR. Gen Appl Plant Phys 33(1-2):3-11

Elshafei A, Barakat M, Milad S, Khattab S, Al-mutlaq M (2019) Regeneration of rice somaclons tolerant to high level of abscisic acid and their characterization via RAPD markers. Bull Nat Res Cent 43:107

Hamideh J, Khosro P, Javad NDM (2012) Callus induction and plant regeneration from leaf explants of Falcaria vulgaris an important medicinal plant. J Med Plants Res 6(18):3407-3414

Huang GC, Chien TY, Chen LG, Wang CC (2005) Antitumor effects of zerumbone from Zingiber zerumbet in P-388D1 cells in vitro and in vivo. Planta Med 71: 219-224

Jantan I, Rafi IAA, Jalil J (2005) Platelet-activating factor (PAF) receptor-binding antagonist activity of Malaysian medicinal plants. Phytomedicine 12:88-92

Jindal VK, Mukherjee S (1970) Structure of alkali-soluble polysaccharide from Phoenix dactylifera seeds. Ind J Chem 8:417-419

Jonoubi P, Mousavi A, Majd A, Salmanian AH, Jalali JM (2005) Efficient regeneration of Brassica napus L. hypocotyls and genetic transformation by Agrobacterium tumefaciens. Biol Plantarum 49:175-180

Joy P, Raja DP (2010) Genetic analysis of somoclonal variation among Jasminum auriculatum (Vohl.) and it's callus. Int J of Biol Techn 1(1):94-98

Kumar S, Joseph L, George M, Sharma A (2011) A review on anticoagulant/ antithrombotic activity of natural plants used in traditional medicine. Int J Pharm Sci Rev and Res 8(1):74-84

Kumar S, Kanwar JK (2007) Plant regeneration from cell suspension in Gerbera gamesonii Bolus, J Fruit Ornam Plant Res. 15:157-166

Larkin PJ, Scowcroft WR (1981) Somaclonal variation: a novel source of variability form cell cultures for plant improvement. TheorAppl Genet 60:197-214

Lashin II, Mamdouh D (2014) Effect of plant growth regulators on callus induction and plant regeneration of cucumber (Cucmissativus L. Beith Alpha). Nat Sci 12(11):68-74

Mendes-Silva W, Assafim M, Ruta B, Monteiro R (2003) Antithrombotic effect of glycyrrhizin, a plant-derived thrombin inhibitor. Thromb Res 112:93-98

Mishra PK, Manivannan B, Pathak N, Sriram S, Bhande SS, Panneerdoss S, Lohiya NK (2003) Status of spermatogenesis and of sperm parameters in langur monkeys following long term vas occlusion with styrene maleic anhydride (SMA). Journal of Andrology (High Wire Press, USA) 24:501-509

Molnár Z, Virág E, Ördög V (2011) Natural substances in tissue culture media of higher plants. Acta Biol Szegediensis 1:123-127

Muller E, Brown PTH, Hartke S, Lorz HTI (1990) DNA variation in tissue culturederived rice plants. Theor Appl Genet 80:673-679

Murashige T, Skoog T (1962) A revised medium for rapid growth and bioassays with tobacco tissue cultures. Phsiol Plant 15:473-497

Naik PM, Al-Khayri JM (2016) Impact of abiotic elicitors on in vitro production of plant secondary metabolites: a review. J Adv Res Biotech 1:1-7

Namdeo AG (2007) Plant cell elicitation for production of secondary metabolites: a review. Pharmacog Rev 1:69-79

Ngara R, Rees J, Ndimba BK (2008) Establishment of sorghum cell suspension culture system for proteomics studies. Afr J Biot 7:744-749

Niu C, Kebede H, Dick L, Auld DL, Woodward JE (2008) A safe inexpensive method to isolate high quality plant and fungal DNA in an open laboratory environment. Afr J of Biot 7(16):2818-2822 
Pierik RLM (1990) Cultivo in vitro de las plant as superiors. Multiprensa publisher, Madrid, España pp: 326

Prakash S, Elangomathavan R, Seshadri S, Kathiravan K, Ignacimuthu S (2004) Efficient regeneration of Curcuma amada Roxb plantlets from rhizome and leaf sheath explants. Plant Cell Tiss Or 78:159-165

Qureshi S, Shah AH, Tariq M, Ageel AM (1989) Studies on herbal aphrodisiacs used in Arab system of medicine. Am J Chin Med 17:57-63

Rehman R, Akram M, Akhtar N, Jabeen Q, Saeed T, Ali SSM (2011) Zingiber officinale Roscoe (pharmacological activity). J Med plants Res 5(3):344-348

Roy A, Ghosh S, Chaudhuri M, Saha PK (2008) Effect of different plant hormones on callus induction in Gymnema sylvestris R.Br. (Asclepia daceae). Afr J Biotechnol 7(13):2209-2211

Sák M, Dokupilova I, Mihalik D, Lakatosova J, Gubisova M, Kraic J (2014) Elicitation of phenolic compounds in cell culture of Vitis vinifera L. by Phaeomoniella chlamydospora. Nova Biotechnol Chim 2:162-171

Sambrook J, Russell D (2000) Molecular cloning: a laboratory manual third edition. Cold Spring Harbour Laboratory press, Newyork, pp 78-85

Sawangjaroen N, Phongpaichit S, Subhadhirasakul S, Visutthi M, Srisuwan N, Thammapalerd N (2006) The anti-amoebic activity of some medicinal plants used by AIDS patients in Southern Thailand. Parasitol Res 98:588-592

Sawangjaroen N, Subhadhirasakul S, Phongpaichit S, Siripanth C, Jamjaroen K, Sawangjaroen K (2005) The in vitro anti-giardial activity of extracts from plants that are used for self-medication by AIDS patients in Southern Thailand. Parasitol Res 95:17-21

Seidel V, Windhövel J, Eaton G, Alfermann AW, Arroo RRJ, Medarde M, Petersen M, Wolley JG (2002) Biosynthesis of podophyllotoxin in Linum album cell cultures. Planta 215:1013-1039

ShikhaJ DCBS, Kaur M, Singh H, Peter J, Kosta S (2014) Plant as anticoagulant/ antihrombotic agent. World J of Pharm Res 3:4573-4585

Somchit MN, Shukriyah MHN, Bustamam AA, Zuraini A (2005) Antipyretic and analgesic activity of Zingiber zerumbet. Int J Pharmacol 1(3):277-280

Sultana A, Hassan L, Ahmad SD, Shah AH, Batool F, Islam MA (2009) In vitro regeneration of ginger using leaf, shoot tip and root explants. Pak J Bot 41(4):1667-1676

Taj Eldin IM, Elmutalib MA, Hiba A, Thowiba S, Elnazeer IH (2016) An in vitro anticoagulant effect of aqueous extract of ginger (Zingiber officinale) rhizomes in blood samples of normal individuals. Ame J of Res Com 4(1): 113-121

Tripathi L, Tripathi JN (2003) Role of biotechnology in medicinal plants. Tro J of Pharm Res 2(2):243-253

Westfall RE (2004) Use of anti-emetic herbs in pregnancy: women's choices, and the question of safety and efficacy. Complement TherNurs Midwifery 10:3036

Yang XB, Gao XD, Han F, Tan RX (2005) Sulfation of a polysaccharide produced by a marine filamentous fungus Phomaherbarum YS4108 alters its antioxidant properties in vitro. Bioch ET Bioph Acta 1725:120-127

Zietkiewicz E, Rafalski A, Labuda D (1994) Genome fingerprinting by simple sequence repeat (SSR)-anchored polymerase chain reaction amplification. Gen 20:176-183

\section{Publisher's Note}

Springer Nature remains neutral with regard to jurisdictional claims in published maps and institutional affiliations.

\section{Submit your manuscript to a SpringerOpen ${ }^{\circ}$ journal and benefit from:}

- Convenient online submission

- Rigorous peer review

- Open access: articles freely available online

- High visibility within the field

- Retaining the copyright to your article

Submit your next manuscript at $\boldsymbol{\nabla}$ springeropen.com 